
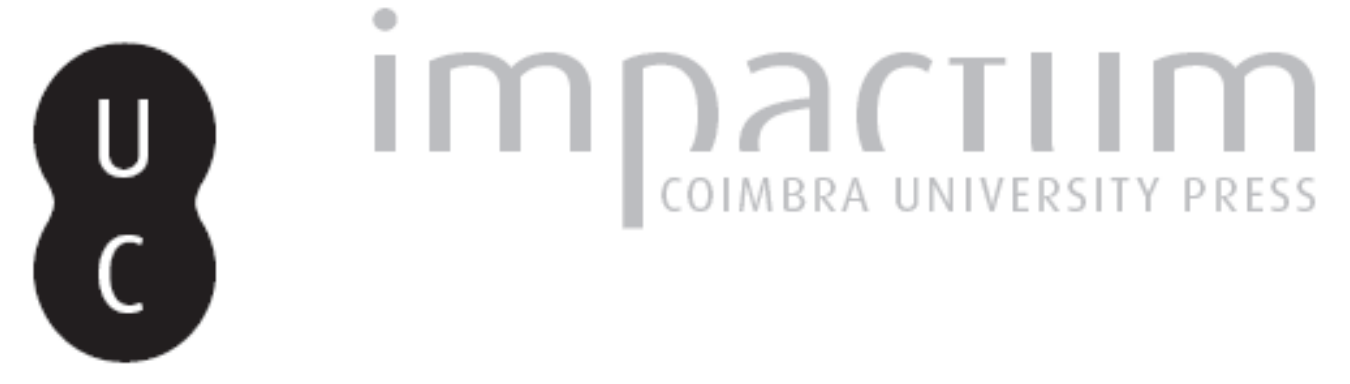

Soccer fans: confronting autocracy online, offline and on the street

Autor(es): Dorsey, James M.

Publicado por: Imprensa da Universidade de Coimbra

URL persistente:

URI:http://hdl.handle.net/10316.2/38256

DOI:

DOI:http://dx.doi.org/10.14195/1647-8622_15_7

Accessed : $\quad$ 26-Apr-2023 10:46:41

A navegação consulta e descarregamento dos títulos inseridos nas Bibliotecas Digitais UC Digitalis, UC Pombalina e UC Impactum, pressupõem a aceitação plena e sem reservas dos Termos e Condições de Uso destas Bibliotecas Digitais, disponíveis em https://digitalis.uc.pt/pt-pt/termos.

Conforme exposto nos referidos Termos e Condições de Uso, o descarregamento de títulos de acesso restrito requer uma licença válida de autorização devendo o utilizador aceder ao(s) documento(s) a partir de um endereço de IP da instituição detentora da supramencionada licença.

Ao utilizador é apenas permitido o descarregamento para uso pessoal, pelo que o emprego do(s) título(s) descarregado(s) para outro fim, designadamente comercial, carece de autorização do respetivo autor ou editor da obra.

Na medida em que todas as obras da UC Digitalis se encontram protegidas pelo Código do Direito de Autor e Direitos Conexos e demais legislação aplicável, toda a cópia, parcial ou total, deste documento, nos casos em que é legalmente admitida, deverá conter ou fazer-se acompanhar por este aviso. 


\section{comunicação, jornalismo e espaço público na era digital}

\section{ESTUD OSD OSÉCULO}

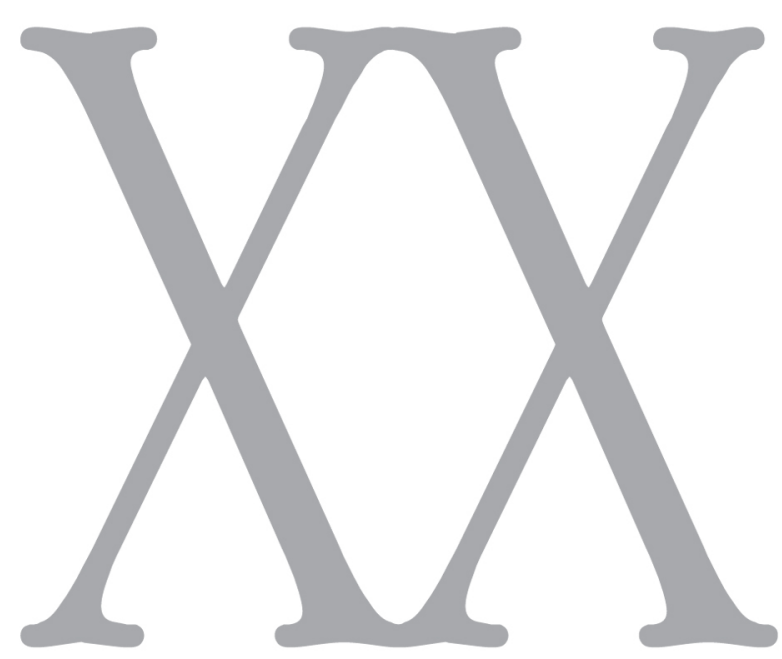

número 15 • 2015

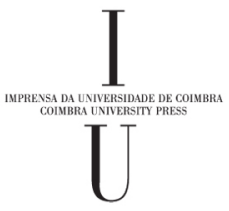




\title{
Soccer fans: \\ confronting autocracy online, offline and on the street
}

\author{
James M. Dorsey
}

James M. Dorsey, Senior fellow at the S. Rajaratnam School of International Studies and co-director of the University of Wuerzburg's Institute for Fan Culture. Email: jmdorsey@questfze.com

http://dx.doi.org/10.14195/1647-8622_15_7 
ADEPTOS DE FUTEBOL: CONFRONTAR A AUTOCRACIA ONLINE, OFFLINE E NA RUA

Os adeptos de futebol, com base na tradição de um século de luta política, têm estado na linha da frente da resistência ao governo autocrático do Egito há quase uma década. As suas lutas têm sido travadas tanto no campo de futebol, na universidade e nas ruas das cidades egípcias em confrontos acesos com as forças de segurança, como online através de páginas de Facebook e contas no Twitter com quantidades imensas de seguidores. Fora da Rede, os adeptos de futebol têm criado formas de expressão altamente organizadas de discórdia e de apoio aos seus clubes, desenharam grafitis para celebrar as suas batalhas e aqueles que morreram em confrontos, editaram cançôes e escreveram poesia. As batalhas online e offline destes adeptos de futebol refletem não só as tensões políticas que se vivem no Egito mas também a importância crescente dos meios de comunicação alternativos e digitais, num país em que os meios de comunicação tradicionais estão confinados por medidas de censura repressivas por uma autocensura autoimposta.

Palavras-chave: Meios de comunicação, Desporto, Protestos, Arte, Médio Oriente.
SOCCER FANS: CONFRONTING AUTOCRACY ONLINE, OFFLINE AND ON THE STREET

Soccer fans, building on a tradition of a century of political engagement, have been at the forefront of resistance to autocratic rule in Egypt for almost a decade. Their battles have been fought as much on the pitch and university campuses and in the streets of Egyptian cities in pitched encounters with security forces as online with Facebook pages and Twitter accounts that have huge followings. Offline, soccer fans have put on display highly choreographed, artistic expressions of dissent and support for their clubs, developed graffiti commemorating their struggles and those who died in confrontations, issued music CDs, and produced poetry. The on and offline battles of the soccer fans reflect not only larger political tensions in Egypt but also the increased significance of online and alternative media in an environment in which traditional media are confined by repressive censorship measures and self-imposed self-censorship.

Keywords: Media, Sports, Protest, Art, Middle East.

\section{LES FANS DE FOOT: CONFRONTATION DE L'AU- TOCRATIE EN LIGNE, HORS LIGNE ET DANS LES RUES}

Les fans de foot, s'appuyant sur une tradition d'un siècle d'engagement politique, ont été aux premiers rangs de la résistance au régime autocratique, en Egypte, pendant presque une décennie. Leurs luttes ont été menées autant sur le terrain, sur les campus universitaires et dans les rues des villes égyptiennes lors de confrontations sur le terrain avec les forces de sécurité, qu'en ligne sur les pages Facebook et les comptes Twitter qui ont de chauds partisans. Hors ligne, les mordus du foot ont exhibé des expressions hautement chorégraphiées et artistiques de leur dissidence et de leur soutien à leurs clubs, des graffiti élaborés commémorant leurs lutes et célébrant ceux qui sont morts lors de confrontations, produit des CDs contenant de la musique, et écrit de la poésie. Les batailles en ligne et hors ligne des mordus du foot reflètent non seulement des tensions politiques plus vastes en Egypte, mais aussi la signification croissante des médias en ligne et des médias alternatifs, dans un environnement dans lequel les médias traditionnels sont restreints par des mesures de censure répressive et une auto-censure auto-imposée.

Mots-clefs: Media, Sports, Protestations, Art, Moyen-Orient. 


\section{Pitches and media: A battleground}

When Sarah Samir stepped in early 2015 on to an Egyptian soccer pitch to referee a men's match, she joined a small band of Arab women referees staking out their right to be involved in the sport on par with men. ${ }^{1}$ Egyptian state-owned and pro-government media were quick to capitalize on the event in their bid to shape Islam in the mould of the country's military-controlled regime and repression of all expressions of dissent. ${ }^{2}$ It was one of numerous battles fought in online, social and traditional media.

The significance of the appearance of Samir, Egypt's first woman referee, highlighted the battle for the soul of Egypt and Islam that is being fought on the pitch as much as it is being waged on multiple other fronts. It also constituted an undeclared effort by the government to pit ordinary soccer fans against militant, highly politicized, street battle-hardened supporters who have put their stamp on the sport since 2007 and played a key role in the toppling in 2011 of President Hosni Mubarak and subsequent anti-government protests. The timing of the government move was significant not only because it followed Egyptian general-turned-president Abdel Fattah Al Sisi's call for a reform of Islam to stem the appeal of jihadism but also coincided with a failed attempt by the government to partially lift a three-year ban on fans attending league matches.

The attempt failed when some 20 fans were killed trying to enter the Cairo stadium where the first match to which a limited number of fans had been admitted was being played. The incident, the worst in Egyptian sporting history after a 2012 politically-loaded soccer brawl in Port Said in which 74 fans died, suggested that Al-Sisi's efforts to build bridges to Egypt's disaffected youth had failed to produce results. It was a picture that repeated itself across the Middle East and North Africa with soccer offering youth who had lost hope of gaining a social and economic stake in society a refuge in the comradery and anti-authoritarian nature of militant soccer groups who used widely popular social media accounts to communicate among themselves and with the outside world.

Middle Eastern and North African soccer pitches are often the indicator of things to come. Pitched battles in stadia between militant soccer fans or ultras and security forces that were reported widely in social media but received at best cursory attention in traditional media during Egyptian president Hosni Mubarak's last four years in office foreshadowed the key role the supporters played in the 2011 popular revolt and mass protests against Mubarak's various successors. Social media were similarly the prime sources for mass anti-government protests in 2013 against then Turkish Prime Minister Recep Tayyip Erdogan in which organized fans also were prominent. The same was true for unprecedented criticism of ruling families in Saudi Arabia, Qatar

\footnotetext{
${ }^{1} \mathrm{Al}$ Arabiya - Egypt's 1st female football referee hits the pitches. (20 January 2015). Available in WWW: <URL: http://english.alarabiya.net/en/sports/2015/01/20/Egypt-s-1st-female-football-referee-hits-thepitches-.html>.

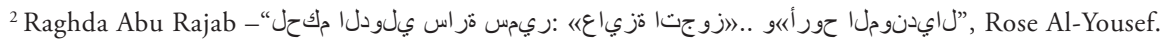

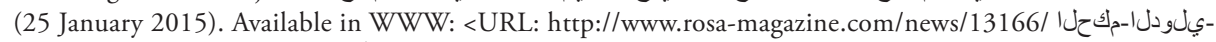

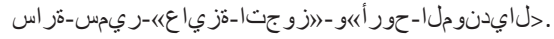


and Jordan expressed on the pitch and protests against Algeria's military autocrats in the country's stadiums. ${ }^{3}$

The projection of Samir's performance by Egyptian state and pro-government media as part of an effort to promote a more inclusive, depoliticized interpretation of Islam and the underlying message that support of soccer teams need not involve violence or politics took on added importance against the backdrop of stadia as political venues. Egypt's foremost state-owned newspaper, Al Ahram, an organ of the regime dating back to the 1952 coup that toppled the monarchy and brought Gamal Abdel Nasser to power, quoted Samir as saying that she had a much easier time than her male counterparts on the pitch.

"I believe that it will be a very good idea if more female referees take charge of men's football matches. Players become highly disciplined when I take charge of any match in the lower divisions. We are in an eastern society where men usually refrain from obscenities in the presence of women. For instance, in the fourth division players usually hurl a barrage of insults but when I refereed some matches in that tier, I found nothing but respect," Samir told the paper. Her message was echoed in other state-owned media as well as the bulk of private Egyptian media that have fallen in line in their support of moves against the Muslim Brotherhood, and Al Sisi's coup in 2013 that deposed President Mohammed Morsi, Egypt's first and only democratically elected leader.

The media's role in publicizing the message highlighted the complex web of censorship and self-censorship in Egypt, a country that theoretically abolished censorship in 1971. Egypt's reality has little in common with the theory. Censorship is prevalent through a complex system of constitutional restrictions of freedom of expression; state-run media; a web of economic and commercial relationships between the state and independent media owners; payments to journalists through the Journalists Syndicate; vaguely-worded laws criminalizing incitement, defamation and rumour-mongering; harassment and persecution of bloggers; and self-censorship by a majority of independent media that have pledged allegiance to the Sisi government. Egypt has some 186 laws on the books that restrict freedom of the press ${ }^{4}$ and the government exercises further control through ownership of most printing plants and distribution facilities.

The myth of the abolishment of censorship was definitively punctured with the government's use of jihadist violence as a pretext for adopting a law in the summer of 2015 that dictated to journalists, bloggers and users of social media terminology they could use to describe the mushrooming insurgency in the Sinai Peninsula and attacks in Egyptian cities. It was a bid to shape discussion of its repressive policies in traditional and online media and control the narrative. The draft law stipulated a minimum two-year sentence for "reporting false information on terrorist attacks that

\footnotetext{
${ }^{3}$ DORSEY, James M. - The Turbulent World of Middle East Soccer. New York: Oxford University Press; London: Hurst, 2016.

${ }^{4}$ United Nations Educational, Scientific and Cultural Organization (UNESCO) - Assessment of Media Development in Egypt. (January 2013) p. 35. Available in WWW: <URL: http://unesdoc.unesco.org/ images/0022/002207/220742e.pdf $\geq$.
} 
contradicts official statements" and allowed the government to deport violators or put them under house arrest. ${ }^{5}$

The law further bans referring to the Islamic State, the jihadist group that controls a swath of Syria and Iraq, as a religious group despite the facts that it bases its ideology on the Muslim holy book and enforces a strict interpretation of Islamic law. The group can however be referred to by its proper name, the Islamic State. The law further authorizes the words terrorists, savages, slayers, and eradicators as legitimate references to members of the group. ${ }^{6}$ "The proposed anti-terrorism law crystallises a two year long policy that seeks to tighten, generally, the police state's grip on Egypt and the autocrat's hold, specifically, on all matters Egyptian," quipped Egyptian journalist Amr Fahmy. ${ }^{7}$

Journalist Ruth Michaelson, reported within hours of publication of a draft of the law that she had received an email from Fact Check Egypt, an office of the State Information Service, demanding that she change a story. "As per Egypt's new counterterrorism draft law, State Info Service just contacted me to ask me to change my reported \# dead soldiers in Sinai," Michaelson tweeted. ${ }^{8}$ In an indication of the government's micro-management of the media even before the law came into effect, SIS also asked Michaelson to explain why she had used anonymous sources in her story on the website of The Daily Beast. ${ }^{\text {T }}$

In a rare engagement with criticism, the government however met in July 2015 with senior editors and agreed to consider amendments to the draft law that would involve fines instead of jail sentences and would require a court to determine that intent and malice had underlay the publication of allegedly 'false' news items. ${ }^{10}$

A jihadist insurgency in the north of the Sinai Peninsula fuelled by decades of neglect and discrimination that threatens to spread to major Egyptian cities where acts of political violence committed by youth, including militant soccer fans, are on the increase, had persuaded the government to expand its engagement with youth on the Internet. In a first initiative, Al Azhar, the government-controlled centre of Islamic learning, launched an online observatory in ten languages to counter jihadist ideology and promote a renewal of religious discourse. The observatory constituted a recognition that youth could be better reached through online media rather than with

\footnotetext{
${ }^{5}$ Agence France Presse - Egypt to jail reporters who 'contradict official statements', (5 July 2015). Available in WWW: <URL: http://www.i24news.tv/en/mobile\#content/77276>.

${ }^{6}$ Middle East Eye - Egypt ministry tell foreign journalists to stop using the term 'Islamic State', (5 July 2015). Available in WWW: <URL: http://www.middleeasteye.net/news/egypt-ministry-tell-foreign-journalists-stop-using-term-islamic-state-809143529>.

${ }^{7}$ KHALIFA, Amr - “Assault on journalism, Al-Sisi style”. Daily News Egypt. (5 July 2015). Available in WWW: <URL: http://www.dailynewsegypt.com/2015/07/05/assault-on-journalism-al-sisi-style/?utm_ source $=$ feedburner $\& u t m \_$medium $=$feed $\& u t m \_c a m p a i g n=F e e d \% 3 A+D a i l y N e w s E g y p t+\% 28 D a i l y+N e w s$ + Egypt $\% 29>$.

${ }^{8}$ MICHAELSON, Ruth - Twitter. (5 July 2015). Available in WWW: <URL: https://twitter.com/_Ms_R>.

${ }^{9}$ MICHAELSON, Ruth - "Egypt's Self-Inflicted Slaughter". The Daily Beast. (4 July 2015). Available in WWW: <URL: http://www.thedailybeast.com/articles/2015/07/03/egypt-s-self-inflicted-slaughter.html>.

${ }^{10}$ Middle East Eye - Egypt signals changes to anti-terror law after media backlash. (9 July 2015). Available in WWW: <URL: http://www.middleeasteye.net/news/egypt-signals-changes-anti-terror-law-after-mediabacklash-155989314>.
} 
conferences and workshops. At the same time, the Ministry of Religious Endowments began training young imams in the use of online communication tools. "There is a Facebook page focusing on correcting misconceptions, in addition to WhatsApp. It is a place where the imams get together on any questions," said Sheikh Ahmet Turk, the head of the imam training. ${ }^{11}$

The messaging involved in coverage of Samir was a precursor of the government effort. Its timing was important given that it came on the back of a media campaign and legal efforts to undermine the credibility of militant soccer fans, respected for their passionate support of the sport and their willingness as one, if not the only, group to have stood up to the brutal security forces under Mubarak and his successors. Months after the government capitalized on Samir to project Egypt as a forward looking nation, an Egyptian court banned ultras as terrorist organizations. The ban coupled with the new media law threatened the ultras on line presence, one of their key infrastructural pillars. The new media law and impositions on the coverage of mounting political violence neatly bookended the process of significantly curtailing independent on- and offline reporting.

The media law acknowledged the importance of not only traditional media but also online media, particularly those based outside of Egypt. Domestic traditional and to a lesser degree online media either voluntarily or by force had become parrots of the regime. Both were increasingly muzzled through a combination of legal restrictions, government-imposed rules, self-censorship and self-appointed, sycophantic support for the regime by privately-owned media.

As a result, online activity took on added significance. "While they (youth) might be side lined politically, they are still very active in civil society, online, in the arts, and in other real and virtual public spaces. Generational change is slow but often inexorable. Although Arab youth may have lost today's battle to hardened forces of yesterday, it is their values and choices that will shape the future," noted Middle East scholar Paul Salem. ${ }^{12}$

Online media in the Middle East and North Africa moreover in terms of eyeballs, clicks and followers suggest that youth often embrace more liberal and democratic values than would be evident from news coverage of the region's struggle with jihadism. Alongside established media and music celebrities, liberal commentators such as Bassem Youssef and Amr Hamzawy are among Egypt's most followed Twitter accounts. Six of the ten most watched YouTube channels in Saudi Arabia are satirical shows produced by rebellious Saudi youth that as of late 2014 had more than 900 million views. ${ }^{13}$

\footnotetext{
${ }^{11}$ MOKBEL, Reham - "Al-Azhar goes online to fight extremism". Al-Monitor. (26 June 2015). Available in WWW: <URL: http://www.al-monitor.com/pulse/originals/2015/06/egypt-al-azhar-internet-social-media-religious.html>.

${ }^{12}$ SALEM, Paul - "The Promise of Arab Youth: Gone Today, Here Tomorrow". The Middle East Institute. (7 July 2015). Available in WWW: <URL: http://www.mei.edu/content/at/promise-arab-youth-gone-today-here-tomorrow>.

${ }^{13}$ BENCHEMSI, Ahmed - "Don't be Fooled by Appearances, Liberal Values are Spreading in the Arab World”. The Middle East Institute. (December 2014). Available in WWW: <URL: http://www.mei. edu/content/article/don $\%$ E2\%80\%99t-be-fooled-appearances-liberal-values-are-spreading-arab-world $>$.
} 
Leaked tapes published by pro-Brotherhood media operating from outside of Egypt laid bare the military's approach to the media and freedom of the press. On a tape published in 2013 by a pro-Brotherhood news website in Turkey, military officers expressed dismay at the degree of public scrutiny to which the armed forced had been subjected since the toppling of Mubarak. They condemned media coverage as "dangerous" and abnormal, called for the re-imposition of "red lines" that had protected the military in the past and urged Al-Sisi to ensure that media owners exercised self-censorship.

While Al-Sisi advised the officers that they would have to adjust to a new era of public and parliamentary oversight, he also asked them for the time to build alliances with the media. "Building a state-wide alliance takes a long time and effort. It takes a very long time until you possess an appropriate share of influence over the media.... The revolution has dismantled all the shackles that were present - not just for us, not just for the military, but for the entire state. The rules and the shackles were dismantled, and they are being rearranged," Al-Sisi said, putting the emphasis of government control on self-censorship. ${ }^{14}$

Al-Sisi nevertheless, addressing a fellow officer by his first name, argued that the military could not "take things back to the way it was before, when nobody mentions your name or talks about you, not yet. We have entered a new situation, and we will be forced, Omar, to deal with it. A Parliament is still coming. This Parliament may request hearings. What are we going to do about that, I wonder? We have to be prepared to face these changes without being too negatively affected by them, but they will affect us." Al-Sisi said he was already working on Omar's suggestion to enter into a dialogue with Egypt's 12 foremost media barons to cajole them into refraining from criticism. "These red lines, Omar, are for all of us. The law, the law, the law does not permit, even now, media outlets to cover any news about the armed forces, Omar, even if just a name in an obituary, without the approval of the military intelligence," Al-Sisi said.

$\mathrm{Al}$ Sisi has proven to be true to his word. Military control of the media was tightened soon after he removed Morsi from power. A designated unit of the armed forces was empowered to approve in advance anything Egyptian media published or broadcast about the military and frequently supplied media with prepared texts. Military officers were placed in key newsrooms. ${ }^{15}$

By and large, journalists shied away from resisting military control. "I would say anything the military tells me to say out of duty and respect for the institution," said Ahmed Moussa, one of Egypt's most popular TV presenters. ${ }^{16}$ Added veteran talk show host Mahmoud Saad: "The military should never, ever, ever be covered. You have to let them decide what to say and when to say it. You don't know what will hurt national security." 17

\footnotetext{
${ }^{14}$ http://www.youtube.com/watch?v=WB9MVTR02YE.

${ }^{15}$ Interview with Egyptian military officer, 24 March 2015.

${ }^{16}$ The Guardian - How Egyptian media has become a mouthpiece for the military state. (26 June 2015). Available in WWW: <URL: http://www.theguardian.com/world/2015/jun/25/egyptian-media-journalism-sisi-mubarak/>.

${ }^{17}$ Ibid, The Guardian
} 
Compliance with the military's censorship was furthered by the cost of refusal. A report by the Committee to Protect Journalists (CPJ) published in June 2015 concluded that more Egyptian journalists were in prison than ever before. It said the government had used the argument of national security to crack down on press freedoms.

"More than half of the journalists on CPJ's census worked online. The Internet, which could be considered the only space left for free speech and independent reporting in Egypt, is becoming increasingly dangerous... The president is expected to sign into law a draft cybercrime bill, framed as anti-terrorism legislation, which allows law enforcement agencies to block websites and pursue heavy prison sentences against Internet users for vaguely defined crimes such as 'harming social peace' and 'threatening national unity.' The potential implications for bloggers and journalists are dire, according to regional experts focusing on information systems and human rights," the report said. ${ }^{18}$

Paradoxically, online media established by hard-hitting independent journalists in the wake of the 2011 revolt such as El Badil ${ }^{19}$ and Mada Masr ${ }^{20}$ have survived as rare independent publications producing the kind of journalism that traditional print and broadcast media would or could not run. In doing so, they walk a fine line never sure if and when the crackdown will affect them. For safety and security reasons, Mada Masr needs to pick its battles. Reporters no longer report protests from the scene because of the risk of being shot or arrested. Similarly trying to report on the insurgency from Sinai has become too much of a physical risk.

Mada Masr's vulnerability is enhanced by the fact that it is funded by among others Denmark's International Media Support and Germany's Rosa Luxemburg Foundation in a country that strictly controls foreign financing of non-governmental organizations. Recipients of foreign funds perceived by the government to be harming the national interest or breaching public peace risk life in prison.

Founded as an outgrowth of the defunct Egypt Independent website, Mada Masr launched on 30 June 2013, the day mass protests erupted which paved the road for the military coup against Mohammed Morsi, Egypt's first and only democratically elected president. Mada Masr was counterintuitive in multiple ways: a company run as a democracy in a country accustomed to hierarchy that had just witnessed a military coup and a mounting crackdown on freedom of the press and dissent. Its stock-in-trade were stories that countered the government's narrative as did its ownership structure.

Mada Masr, unlike most Egyptian media that are part of conglomerates with an interest in ensuring that they are in good standing with the government, is owned by young journalists who had been shaped by the 2011 revolt. The website's founder, Lina Attalah, was punched by police and dragged through the street on the first day of the revolt. "For our own credibility, it's important to be seen as an independent newspaper. There's nothing easier than being radical - it's the easy way out. But we

\footnotetext{
${ }^{18}$ Committee to Protect Journalists - Egypt's imprisonment of journalists is at an all-time high. (25 June 2015). Available in WWW: <URL: https://cpj.org/reports/2015/06/egypt-imprisonment-of-journalists-is-at-an-all-time-high.php\#more>.

${ }^{19}$ https://elbadil.com/

${ }^{20}$ http://www.madamasr.com/ar
} 
want to reach out and negotiate a space for ourselves. You want to have impact," Attalah told The Guardian. "We took the decision to exist in a very contentious and dangerous moment. If we take a step that courageous, we have to go on," added Mai Shams El-Din, a Mada Masr reporter. ${ }^{21}$

The contrast in reporting between Mada Masr and the bulk of Egypt's media was evident within days of the coup. Supporters of Morsi had camped out in front a Republican Guard clubhouse where the deposed president was believed to have been detained. Mada Masr's story described an early morning coordinated assault by the military who used tear gas, birdshot and live ammunition. Sixty-one people died and 435 were injured in the assault. ${ }^{22}$ The story involved sending a photographer to the scene, visits to hospital wards and interviews with residents in the area. By contrast, the bulk of the Egyptian media reported that the Republican Guard facility had been stormed by armed terrorists belonging to the Muslim Brotherhood.

Despite the likes of Mada Masr, Al-Sisi's successful media strategy was evident in coverage of the ultras. "Will the Ultras be shown the red card after crossing the red line? Are they digging their own grave? ... Football Ultras of soccer powerhouse Egyptian clubs Ahli and Zamalek have become a dangerous phenomenon... These days the Ultras are a symbol of destruction, attacking the opposition and sometimes their own kind," Al Ahram warned, preparing the ground for multiple court cases against members of the ultras and ultimately the banning of the soccer support groups. ${ }^{23}$

The paper's focus on the ultras followed a series of incidents in which supporters of storied Cairo clubs Al Ahli SC and Al Zamalek SC attacked their clubs and players, demanding resignation of company officials. It came in advance of an attempt by Zamalek's management with Al-Sisi's tacit backing to have the courts outlaw the Ultras White Knights (UWK), the club's militant support group, outlawed as a terrorist organization. Mamdouh Abbas, Zamalek's chairman at the time of Al Ahram's comments, rejected the calls for him to step down, saying that he would only leave his post if club members adopted a motion of confidence, not in response to the "terror of the Ultras". ${ }^{24}$ Abbas urged the military-backed government to take action against the Ultras White Knights (UWK), the militant Zamalek support group, whom he denounced as sports terrorists.

Abbas' successor, Mortada Mansour, a controversial larger-than-life fixture of the Mubarak era and close associate of Al Sisi, picked up the ball by initiating a series of

\footnotetext{
${ }^{21}$ CHANG, Leslie T - “The news website that's keeping press freedom alive in Egypt". The Guardian. (27 January 2015). Available in WWW: <URL: http://www.theguardian.com/news/2015/jan/27/-sp-online-newspaper-keeping-press-freedom-alive-egypt>.

${ }^{22}$ MASR, Mada - Update: 51 killed in clashes at Republican Guards HQ. (8 July 2015). Available in WWW: <URL: http://www.madamasr.com/news/update-51-killed-clashes-republican-guards-hq> / MOHSEN, Ali Abdel - “The killing of Islamist protesters: State censorship or self-censorship?”. Mada Masr. [Consult 9 July 2013]. Available in WWW: <URL: http://www.madamasr.com/news/killing-islamist-protesters-state-censorship-or-self-censorship $>$.

${ }^{23}$ MAZHAR, Inas - "Ultra-violent". Al Ahram Weekly. (26 September 2013). Available in WWW: <URL: http://weekly.ahram.org.eg/News/4236/17/Ultra-violent.aspx>.

${ }^{24}$ DORSEY, James M. - "Turkish and Egyptian ultras fight for their existence”. (30 September 2013). Available in WWW: <URL: http://mideastsoccer.blogspot.sg/2013/09/turkish-and-egyptian-ultras-fight-for. html>.
} 
court cases in which he charged that UWK were e terrorists who sought to assassinate him. Denying the allegations that led to the arrest of scores of UWK members, the group dubbed Mansour 'the regime's dog' in its online media. ${ }^{25}$

Traditional media contributed on and offline their part with a frontal attack on the ultras who pride themselves on their financial independence. Officials of Al Ahli and Zamalek were quoted as suggesting that they were being funded by third parties and challenged them to make their finances public. "Now it is not only firecrackers but also bird shot that is being used in attacking us. They don't spend money on tickets anymore but spend it to destroy the club," Abbas said. ${ }^{26}$ Al Ahram noted that the ultras "spend much money on their trips buying tickets and firecrackers and other tools to support the teams. Their social background doesn't show that they have that kind of money. Their main income comes from selling T-shirts." 27

Major General Talaat Tantawi, a retired military officer-turned security consultant, charged in media interviews that the ultras much like their counterparts in Argentina were being manipulated by groups seeking to exploit their popularity. "It is so easy to penetrate these groups and make use of their enthusiasm and youth. They have become easy targets to achieve political goals and to distract them from focusing on their main vision and mission which was supporting sports. Others joined in and became Ultras and are acting as we see now," Tantawi said ignoring the fact that the ultras were politicized and steeled in years of confrontations with security forces during the Mubarak era.

The media and legal attacks acknowledged the fact that the ultras' battle in Egypt for freedom in the stadia, their prominent role in the toppling of Mubarak, their opposition to the military rulers and the elected and then toppled Brotherhood government of Mohammed Morsi, and their role in anti-Sisi protests in universities across the country, made them political by definition. They embraced the principle of ACAP, All Cops Are Pigs, shared by ultras worldwide, more fervently because their confrontations with security forces extended beyond the stadia and protest squares to popular neighbourhoods of cities where corrupt police made life difficult for them as well as their families.

Media focus on the ultras was sharpened by the key role played by Ultras Nahdawy (Ultras Renaissance) in persistent student protests on university campuses and in local neighbourhoods in the Egyptian capital against Al Sisi's repressive regime and in favour of academic and other freedoms. Nahdawy, whose name refers to the term used by the Brotherhood to describe its political and economic program, is the only militant soccer group that openly identifies itself as political and is not aligned with a club. Its communications largely outfox the government through savvy use of the Internet and social media.

\footnotetext{
${ }^{25}$ Ahram Online - Zamalek's Ultras White Knights posts chairman Mansour assault video. (13 October 2014). Available in WWW: <URL: http://english.ahram.org.eg/NewsContent/6/0/112943/Sports/0/ Zamaleks-Ultras-White-Knights-posts-chairman-Manso.aspx >.

${ }^{26}$ Ibid. DORSEY

${ }^{27}$ Ibid., Al Ahram Weekly
} 
Formed by members of Ultras Ahlawy, the well-organized and street battled-hardened militant support group of Al Ahli FC that played a key role in the popular uprising and protests in recent years, and UWK members who sympathized with the Brotherhood that has been brutally suppressed by the Al Sisi regime and outlawed by Saudi Arabia and the United Arab Emirates, Ultras Nahdawy has since distanced itself from the Brothers. Nahdawy's leadership consists largely of soccer-crazy university students while its rank and file are often still in high school. "We took the culture of the ultras in the stadiums and tried to copy and paste it into the street," a Nahdawy member and Ahli supporter told The Los Angeles Review of Books.

The sentencing in May 2014 by an Egyptian court of twelve militant soccer fans to five years in prison in an expansion of the military-backed regime's crackdown on its Islamist and non-Islamist opponents potentially re-positioned soccer as a major platform of protest. The fans, members of Ahlawy, were sentenced in absentia for organizing an illegal gathering and vandalism. The convicted were accused of blocking a Cairo road to protest the arrest of Ahlawy members who eight months earlier had clashed with police as they attempted to storm Cairo airport's international terminal.

The verdict came as Al Sisi defended Egypt's draconian anti-protest law. The law was part of a regional trend visible in Saudi Arabia and Turkey as well as in debates in Jordan that equated protest with terrorism or categorized it as a precursor to political violence. "We are talking about a country going to waste. People must realize this and support us. Whoever imagines otherwise, only wants to sabotage Egypt and this won't be allowed. This chaos will bring it down, because of this irresponsible protesting," Al-Sisi, according to Egyptian media reports, warned, adding that he would do "whatever it takes to restore security."

The verdict against the fans and the crackdown that involved greater brutality by security forces than during the Mubarak era came as power within Egypt's various militant fan or ultras groups had shifted from their highly politicized founders to charismatic young men, who were often un- or under-employed and un-or under-educated, and whose opposition on law enforcement that has made their lives difficult was visceral. "All the old people have left. There was a fight within the group. Some were kidnapped and held for three days. We were attacked with knives. People were injured. Their leader is enormously charismatic," said a founder of one of more prominent group of ultras.

The former ultra who keeps close contact with militant fans said a recent fall in soccer protests fuelled by the ban on spectators attending soccer matches in a bid to prevent stadia from again becoming a platform of anti-government agitation was in part due to a pledge by the interior minister to replace security forces in stadia with private security firms. 'It's likely to be the quiet before the storm. I don't know a single young person who voted in the presidential election. Even my parents, simple people who are not Islamists, don't believe in what is happening. People will lose faith in the military. They are losing faith in everything," he said. Manipulation of the media has so far done little to help Al Sisi turn the tide. 


\section{Conclusion}

Battles for Egypt's future are being fought on multiple levels from the violent clashes between security forces and jihadist insurgents in the Sinai Peninsula to increasingly sporadic flash protests in universities and popular neighbourhoods. The battles are reflected in on and offline media with the government largely controlling the narrative through a complex web of imposed and self-censorship. Nevertheless, pockets of independent or alternative media continue to manage to portray a different reality. Those media include a few independent Egypt-based news websites that carefully manoeuvre the pitfalls of a brutal crackdown that could touch them at any time as well as the employment of social media by a host of different groups including jihadists, soccer fans, and youth groups as well as opposition media operating from outside the country. While Egypt remains a deeply polarized country, on and offline anecdotal as well as hard evidence suggests that the Al Sisi regime's control has failed to completely silence its critics, including some within the ranks of the armed forces. With half of Egypt's youth under the age of 25, the battle for Egypt's future is shifting from traditional to new media, a terrain on which the government despite repressive controls and snooping technology is still playing catch-up.

\section{Bibliography}

AGENCE FRANCE PRESSE - Egypt to jail reporters who 'contradict official statements', (5 July 2015). Available in WWW: <URL: http://www.i24news.tv/en/mobile\#content/77276>.

Ahram Online - Zamalek's Ultras White Knights posts chairman Mansour assault video. (13 October 2014). Available in WWW: <URL: http://english.ahram.org.eg/NewsContent/6/0/112943/ Sports/0/Zamaleks-Ultras-White-Knights-posts-chairman-Manso.aspx>.

Al Arabiya - Egypt's 1st female football referee hits the pitches. (20 January 2015). Available in WWW: <URL: http://english.alarabiya.net/en/sports/2015/01/20/Egypt-s-1st-femalefootball-referee-hits-the-pitches-.html>.

BENCHEMSI, Ahmed - "Don't be Fooled by Appearances, Liberal Values are Spreading in the Arab World". The Middle East Institute. (December 2014). Available in WWW: <URL: http://www.mei.edu/content/article/don\%E2\%80\%99t-be-fooled-appearances-liberal-valuesare-spreading-arab-world>.

CHANG, Leslie T - "The news website that's keeping press freedom alive in Egypt". The Guardian. (27 January 2015). Available in WWW: <URL: http://www.theguardian.com/ news/2015/jan/27/-sp-online-newspaper-keeping-press-freedom-alive-egypt>.

COMMITTEE TO PROTECT JOURNALISTS - Egypt's imprisonment of journalists is at an all-time high. (25 June 2015). Available in WWW: <URL: https://cpj.org/reports/2015/06/ egypt-imprisonment-of-journalists-is-at-an-all-time-high.php\#more>.

DORSEY, James M. - "Turkish and Egyptian ultras fight for their existence”. (30 September 2013). Available in WWW: <URL: http://mideastsoccer.blogspot.sg/2013/09/turkish-andegyptian-ultras-fight-for.html>. 
DORSEY, James M. - The Turbulent World of Middle East Soccer. New York: Oxford University Press; London: Hurst, 2015.

http://www.madamasr.com/ar

http://www.youtube.com/watch?v=WB9MVTR02YE.

https://elbadil.com/

Interview with Egyptian military officer, 24 March 2015.

KHALIFA, Amr - "Assault on journalism, Al-Sisi style". Daily News Egypt. (5 July 2015). Available in WWW: <URL: http://www.dailynewsegypt.com/2015/07/05/assault-onjournalism-al-sisi-style/?utm_source=feedburner\&utm_medium=feed\&utm_campaign=Fe ed $\% 3 \mathrm{~A}+$ DailyNewsEgypt+\%28Daily+News+Egypt $\% 29>$.

MASR, Mada - Update: 51 killed in clashes at Republican Guards HQ. (8 July 2015). Available in WWW: <URL: http://www.madamasr.com/news/update-51-killed-clashes-republicanguards-hq> 1

MAZHAR, Inas - "Ultra-violent". Al Ahram Weekly. (26 September 2013). Available in WWW: <URL: http://weekly.ahram.org.eg/News/4236/17/Ultra-violent.aspx>.

MICHAELSON, Ruth - "Egypt's Self-Inflicted Slaughter". The Daily Beast. (4 July 2015). Available in WWW: <URL: http://www.thedailybeast.com/articles/2015/07/03/egypt-sself-inflicted-slaughter.html>.

MICHAELSON, Ruth - Twitter. (5 July 2015). Available in WWW: <URL: https://twitter. com/_Ms_R>.

MIDDLE EAST EYE - Egypt ministry tell foreign journalists to stop using the term 'Islamic State', (5 July 2015). Available in WWW: <URL: http://www.middleeasteye.net/news/egyptministry-tell-foreign-journalists-stop-using-term-islamic-state-809143529>.

MIDDLE EAST EYE - Egypt signals changes to anti-terror law after media backlash. (9 July 2015). Available in WWW: <URL: http://www.middleeasteye.net/news/egypt-signals-changes-antiterror-law-after-media-backlash-155989314>.

MOHSEN, Ali Abdel - "The killing of Islamist protesters: State censorship or self-censorship?”. Mada Masr. [Consult 9 July 2013]. Available in WWW: <URL: http://www.madamasr.com/ news/killing-islamist-protesters-state-censorship-or-self-censorship>.

MOKBEL, Reham - "Al-Azhar goes online to fight extremism". Al-Monitor. (26 June 2015). Available in WWW: <URL: http://www.al-monitor.com/pulse/originals/2015/06/egypt-alazhar-internet-social-media-religious.html>.

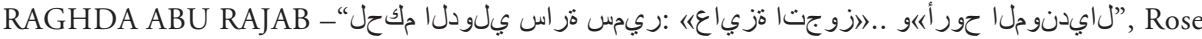
Al-Yousef. (25 January 2015). Available in WWW: <URL: http://www.rosa-magazine.com/

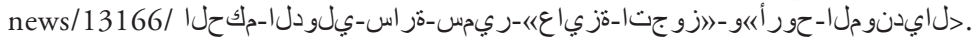

SALEM, Paul - "The Promise of Arab Youth: Gone Today, Here Tomorrow”. The Middle East Institute. (7 July 2015). Available in WWW: <URL: http://www.mei.edu/content/at/ promise-arab-youth-gone-today-here-tomorrow $>$.

THE GUARDIAN - How Egyptian media has become a mouthpiece for the military state. (26 June 2015). Available in WWW: <URL: http://www.theguardian.com/world/2015/jun/25/ egyptian-media-journalism-sisi-mubarak/>.

UNITED NATIONS EDUCATIONAL, SCIENTIFIC AND CULTURAL ORGANIZATION (UNESCO) - Assessment of Media Development in Egypt. (January 2013) p. 35. Available in WWW: <URL: http://unesdoc.unesco.org/images/0022/002207/220742e.pdf>. 